\title{
Effects of recombinant GM-CSF and IgA opsonisation on neutrophil phagocytosis of latex beads coated with P6 outer membrane protein from Haemophilus influenzae
}

\author{
David Burnett, Anita Chamba, Robert A Stockley, Timothy F Murphy, Susan L Hill
}

\begin{abstract}
Background-IgA is the major antibody class in mucosal secretions, yet its biological functions remain poorly understood and its role as an opsonin for neutrophils has been the subject of controversy. It has been reported that treatment of neutrophils with granulocyte-macrophage colony stimulating factor (GM-CSF) induces the cells to phagocytose particles opsonised with IgA. A study was performed to investigate the effects of GM-CSF and IgA opsonisation on the ability of human neutrophils to recognise and phagocytose latex beads coated with the P6 outer membrane protein of Haemophilus influenzae.
\end{abstract}

Methods-Human neutrophils with and without preincubation with $100 \mathrm{pmol} / \mathrm{l}$ GM-CSF, were incubated with nonopsonised P6-coated latex beads or beads opsonised with IgA purified from the blood of a bronchiectatic patient with high titres of IgA anti-P6. Phagocytosis was measured by counting internalised beads during microscopic examination. Results-The phagocytosis of IgA opsonised beads by untreated neutrophils (mean (SE) $2.1 \quad(0.43)$ beads/cell) was significantly greater than that of non-opsonised beads (mean (SE) 1.3 $(0 \cdot 30)$ beads/cell). Treatment of neutrophils with GM-CSF resulted in increased phagocytosis of non-opsonised beads (mean (SE) $2 \cdot 1(0 \cdot 39)$ beads/cell) but opsonisation with IgA increased this further (mean (SE) 3.4 (0.53) beads/cell). Conclusions-Human neutrophils recognise and phagocytose non-opsonised particles coated with bacterial antigen. Antibodies of the IgA isotype opsonise for neutrophil phagocytosis of particles coated with bacterial antigen but this behaviour is enhanced, in an additive fashion, by treatment of the cells with GM-CSF. The results suggest that IgA and GM-CSF are important cofactors for neutrophil recognition and elimination of bacterial pathogens.

(Thorax 1993;48:638-642)

Non-typeable Haemophilus influenzae is an important cause of respiratory tract infection in several lung diseases including chronic bronchitis, bronchiectasis, and cystic fibrosis. ${ }^{1-5}$ The sputum and serum of patients with chronic obstructive pulmonary diseases contain IgG and IgA antibodies to outer membrane proteins of the patients' own isolates of $H$ influenzae. ${ }^{6}$ Nevertheless, the functional capabilities of these antibodies and their role in protection from infection are not clear. The relatively high concentrations of immunoglobulin A (IgA) in the lung, ${ }^{7}$ and the association of IgA deficiency with recurrent infections, suggest that this immunoglobulin class might have an important role in the antimicrobial defences of the lungs and other mucosal sites.

The biological effects of IgA have, however, remained obscure. Some reports have suggested that human IgA is unable to act as an opsonin for human neutrophils, ${ }^{8-11}$ while others have presented evidence that it can. ${ }^{12-15}$ Weisbart et $a l^{16}$ showed that neutrophils treated with granulocyte-macrophage colony stimulating factor (GM-CSF) or granulocyte colony stimulating factor phagocytosed significantly greater numbers of casein-coated latex beads that had been opsonised with IgA antibodies to casein. This effect was associated with the increased expression, on the neutrophils, of high affinity receptors for IgA. These results would suggest that the opsonic effect of IgA may depend upon the IgA receptor status of the neutrophils. The release of colony stimulating factors during infections could therefore significantly increase the ability of neutrophils at inflammatory sites to recognise and dispose of bacteria opsonised with IgA.

The purpose of the present study was to investigate the effects of GM-CSF on the ability of neutrophils to phagocytose an IgA opsonised surface antigen of $H$ influenzae. The P6 outer membrane protein was chosen for study because it is present in all strains of $H$ influenzae. ${ }^{17}$ It is antigenically conserved among strains ${ }^{17}$ and it is known to be the target of functional human antibodies. ${ }^{18}$

\section{Methods}

PURIFICATION OF P6 OUTER MEMBRANE PROTEIN

$H$ influenzae P6 outer membrane protein was isolated from the respiratory tract secretions (expectorated sputum) of patients with 
bronchiectasis by a modification of a method described previously. ${ }^{18} H$ influenzae was cultured from the secretions on brain/heart infusion agar plates supplemented with 10 $\mu \mathrm{g} / \mathrm{ml}$ hemin and $10 \%(\mathrm{v} / \mathrm{v})$ nicotinamide adenine dinucleotide (NAD). The organisms were verified, by biotyping and serotyping, to be non-typeable $H$ influenzae. The bacteria were grown overnight in brain/heart infusion broth containing hemin and NAD maintained at $36^{\circ} \mathrm{C}$ in $5 \% \mathrm{CO}_{2} / 95 \%$ air. The bacteria were harvested by centrifugation at $11000 \mathrm{~g}$ for 30 minutes at $4^{\circ} \mathrm{C}$ and resuspended in 15 $\mathrm{mmol} / 1 \mathrm{NaCl}$, buffered to $\mathrm{pH} 7 \cdot 2$ with 0.01 $\mathrm{mol} / 1$ phosphate buffer and centrifuged again at $11000 \mathrm{~g}$ before resuspension in buffer $\mathrm{B}$ comprising $0.1 \mathrm{~mol} / 1 \mathrm{Tris} / \mathrm{HCl}, \mathrm{pH} 8.0$ containing $0.5 \mathrm{~mol} / 1 \mathrm{NaCl}, 1 \%(\mathrm{w} / \mathrm{v})$ sodium dodecyl sulphate (SDS), and $0 \cdot 1 \%(\mathrm{w} / \mathrm{v}) \beta$ mercaptoethanol. The suspension was sonicated with a Lucas Dawes Ultrasonics Soniprobe and then incubated at $37^{\circ} \mathrm{C}$ for 30 minutes before centrifugation at $21000 \mathrm{~g}$ for 30 minutes. The supernatant was discarded and the pellet resuspended in $30 \mathrm{ml}$ of buffer B. This procedure was repeated twice and the resuspended material was incubated at $37^{\circ} \mathrm{C}$ for one hour with $10 \mu \mathrm{g} / \mathrm{ml}$ ribonuclease A (Sigma, Poole, Dorset, UK). The preparation was centrifuged at $21000 \mathrm{~g}$ and the pellet resuspended in buffer $B$ and incubated again with ribonuclease $\mathrm{A}$ for one hour at $37^{\circ} \mathrm{C}$. Following centrifugation $(21000 \mathrm{~g}, 30 \mathrm{~min}$ utes), the pellet was resuspended in $0.1 \mathrm{~mol} / 1$ sodium tetraborate buffer, $\mathrm{pH} 9 \cdot 5$, and incubated at $65^{\circ} \mathrm{C}$ for 30 minutes before further centrifugation at $100000 \mathrm{~g}$ for one hour at $30^{\circ} \mathrm{C}$. The supernatant was collected and concentrated approximately ten fold by pressure filtration with an Amicon PM10 membrane to remove residual SDS. This final procedure was repeated four times before assessment of purity by SDS polyacrylamide gel electrophoresis.

\section{ISOLATION OF IgA ANTIBODIES}

Venous blood was collected from a patient with radiologically proven bronchiectasis who regularly produced sputum infected with non-typeable $H$ influenzae. The blood of this subject was known to contain high titres of IgA antibodies to outer membrane proteins of $H$ influenzae, determined by enzyme linked immunosorbent assay and Western blotting. ${ }^{19}$ The venous blood was allowed to clot and the serum dialysed exhaustively with $0.01 \mathrm{~mol} / 1$ phosphate buffer, $\mathrm{pH} 8.0$, containing 0.01 $\mathrm{mol} / \mathrm{l} \mathrm{NaCl}$ (PBS). The dialysed serum was applied to a $9 \times 2 \mathrm{~cm}$ column packed with DEAE-Sephacel (Pharmacia, Uppsala, Sweden) which had been equilibrated with PBS. The serum was pumped onto the column at $0.3 \mathrm{ml} / \mathrm{min}$ followed by elution at the same rate with PBS. The column eluate was monitored by spectroscopy at $280 \mathrm{~nm}$ and, after non-bound protein had been recovered, the column was eluted with a linear salt gradient of $0.01-0.1 \mathrm{~mol} / 1 \mathrm{NaCl}$ in $0.01 \mathrm{~mol} / 1$ phosphate buffer, $\mathrm{pH} 8 \cdot 0$, with continuous collection of $0.5 \mathrm{ml}$ fractions. The column was finally eluted with $0.01 \mathrm{~mol} / 1$ phosphate buffer, $\mathrm{pH} 8.0$, containing $0.5 \mathrm{~mol} / 1 \mathrm{NaCl}$. All material collected was investigated for the presence of IgA and IgG using commercially available radial immunodiffusion plates (The Binding Site, University of Birmingham Research Institute, UK). The IgG was detected only in the unbound protein fractions and IgA was collected in the final elution with 0.5 $\mathrm{mol} / \mathrm{l} \mathrm{NaCl}$. The IgA was purified further by immunoadsorption. Sheep antihuman IgA (The Binding Site, Birmingham) was coupled to cyanogen bromide activated sepharose (Pharmacia) using the manufacturer's recommended protocol to give $30 \mathrm{mg}$ antibody on $2 \mathrm{ml}$ of gel, which was equilibrated in a column with $0.05 \mathrm{~mol} / 1$ Tris $/ \mathrm{HCl}$ buffer, $\mathrm{pH}$ $8 \cdot 8$, containing $0 \cdot 1 \mathrm{~mol} / 1 \mathrm{NaCl}$. The IgA-containing material obtained from the ion exchange column was dialysed with 0.05 $\mathrm{mol} / 1 \mathrm{Tris} / \mathrm{HCl}, \mathrm{pH} 8 \cdot 8$, and $0.1 \mathrm{~mol} / 1 \mathrm{NaCl}$, pumped onto the column, and the eluate monitored at $280 \mathrm{~nm}$ until the absorbance returned to the baseline level. The column was then eluted with $0.2 \mathrm{~mol} / 1$ glycine $/ \mathrm{HCl}$, pH $2 \cdot 5$, with $0 \cdot 1 \mathrm{~mol} / 1 \mathrm{NaCl}$, and the material collected onto solid Tris. When the absorbance at $280 \mathrm{~nm}$ had again returned to baseline the collected material was dialysed with $1.5 \mathrm{mmol} / 1 \mathrm{NaCl}$ and concentrated ten fold on a Speedvac before being stored in aliquots at $-40^{\circ} \mathrm{C}$. Assay of this material with radial immunodiffusion plates (The Binding Site, Birmingham) showed it to contain 0.01 $\mathrm{mg} / \mathrm{ml}$ IgA.

\section{ISOLATION OF BLOOD NEUTROPHILS}

Venous blood from five healthy volunteers was collected into lithium heparin anticoagulant. Neutrophils were isolated by centrifugation on Percoll density gradients. ${ }^{20}$ Each blood sample was diluted with an equal volume of $0.15 \mathrm{~mol} / 1 \mathrm{NaCl}$ solution and layered carefully onto $2 \mathrm{ml}$ of $1.075 \mathrm{~g} / \mathrm{ml}$ Percoll (Pharmacia AB, Uppsala, Sweden) in 0.15 $\mathrm{mol} / 1 \mathrm{NaCl}$ which had been layered over $3 \mathrm{ml}$ of $1.096 \mathrm{~g} / \mathrm{ml}$ Percoll. The tubes were centrifuged at $400 \mathrm{~g}$ for 25 minutes and the neutrophils harvested from the interface between the two Percoll layers. The cells were washed twice in Tris buffered RPMI 1640 medium (Flow Laboratories, Rickmansworth, UK), counted, and resuspended in medium. The cells were $>96 \%$ neutrophils and viability, assessed by exclusion of trypan blue, was $>98 \%$. All reagents were assayed for endotoxin with the KabiVitrum Coatest (Flow Laboratories) and contained less than $20 \mathrm{ng} / \mathrm{l}$.

\section{PHAGOCYTOSIS ASSAY}

Polystyrene beads of average diameter $30 \mu \mathrm{m}$ (Sigma, Poole, Dorset, UK) were washed and suspended in a $1 \mathrm{mg} / \mathrm{ml}$ solution of $\mathrm{P} 6$ in $0.01 \mathrm{~mol} / 1$ carbonate/bicarbonate buffer, $\mathrm{pH}$ $9 \cdot 6$, overnight at $4^{\circ} \mathrm{C}$. The polystyrene beads coated with $\mathrm{P} 6$ were washed with $0.015 \mathrm{~mol} / 1$ $\mathrm{NaCl}$ and the purified IgA was added and mixed gently for one hour at room temperature. The beads were washed with $0.15 \mathrm{~mol} / 1$ $\mathrm{NaCl}$ and resuspended in hepes buffered 
Figure 1 Frequency distributions of polystyrene beads phagocytosed by human neutrophils. $(A)$ Beads coated with P6 phagocytosed by control cells not treated with GM-CSF; (B) P6-coated beads phagocytosed by cells treated with GM-CSF;

(C) P6-coated beads opsonised with IgA phagocytosed by cells not treated with GM-CSF; (D) P6-coated beads opsonised with IgA phagocytosed by cells treated with GM-CSF.
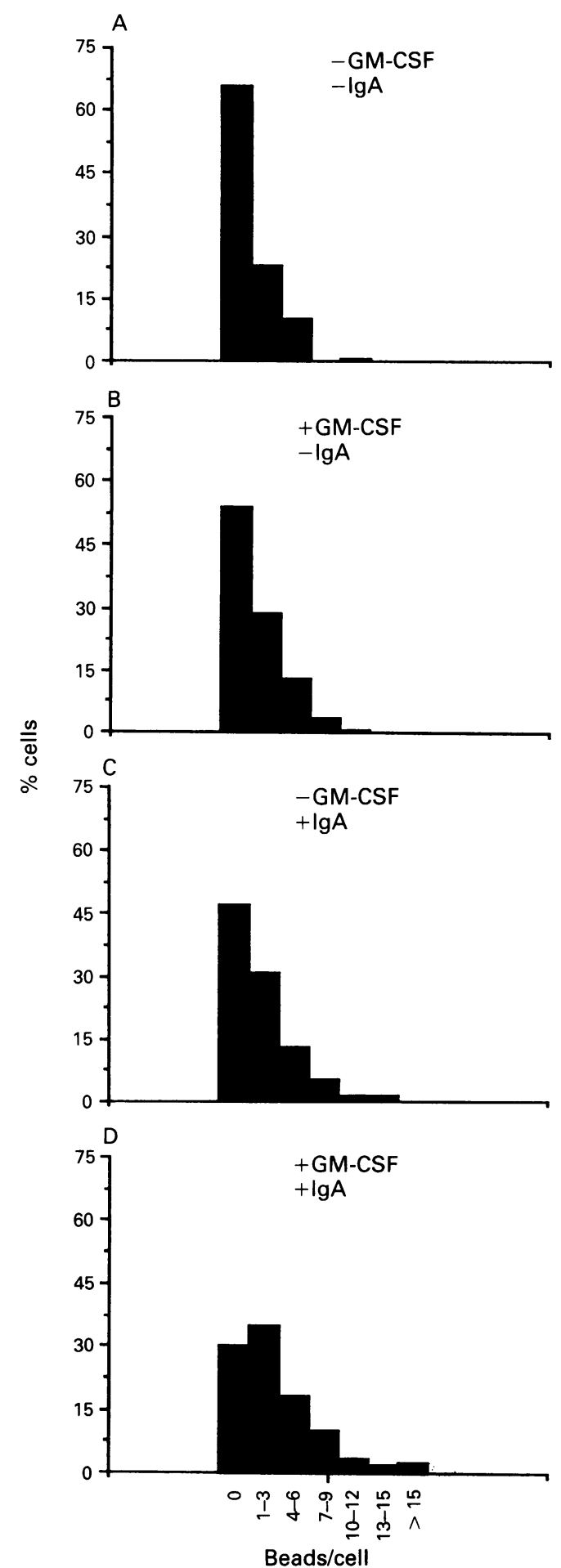

RPMI 1640 cell culture medium (Flow Laboratories).

The neutrophil preparations from the five donors were suspended in hepes buffered RPMI 1640. One half of each neutrophil preparation was incubated with $100 \mathrm{pmol} / 1$ GM-CSF $\left(5 \times 10^{7} \mathrm{CFU} / \mathrm{mg}\right.$ obtained from Genzyme Biochemicals, Maidstone, UK) for 30 minutes at $37^{\circ} \mathrm{C}$; the remainder were incubated with medium only. The GM-CSF treated and untreated neutrophils $(25 \mu \mathrm{l}$ at $5 \times 10^{6} / \mathrm{ml}$ ) were added to $10^{8} \mathrm{P} 6$-coated beads $(25 \mu \mathrm{l})$, with and without opsonisation with $\operatorname{Ig} \mathrm{A}$, in the wells of Multitest slides

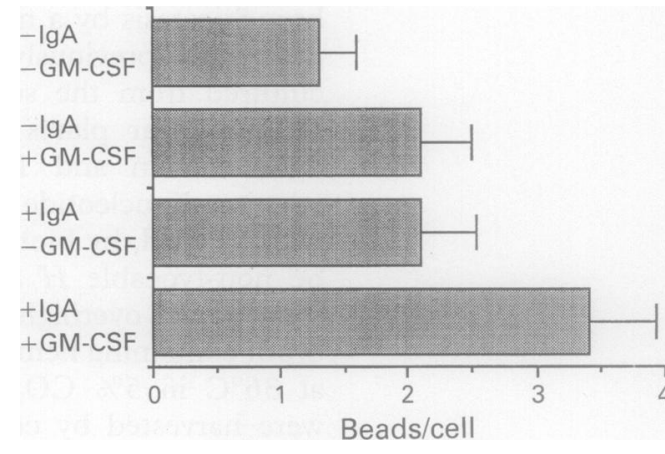

Figure 2 Mean (SE) numbers of polystyrene beads phagocytosed by neutrophils from five healthy subjects. Controls were unopsonised beads and cells not treated with GM-CSF (-IgA, -GM-CSF). Results are also shown for unopsonised beads with cells treated with GM-CSF (-IgA, + GM-CSF; $p<0.01 v$ controls), IgA opsonised beads with cells not treated with $G M-C S F(+\operatorname{Ig} A,-G M-$ CSF: $p<0.05$ v controls), and IgA opsonised beads with cells treated with $G M-C S F(+I g A,+G M-C S F ; p<$ $0.02 v$ all other treatments).

(Flow Laboratories). All treatments were incubated, in quadruplicate at $37^{\circ} \mathrm{C}$ for 20 minutes, after which the slides were washed gently with $0.15 \mathrm{~mol} / 1 \mathrm{NaCl}$ solution and stained with Diff-Quik (Travenol). Each preparation was examined at $\times 400$ magnification under oil immersion and the number of beads/cell counted in at least 200 cells/well, care being taken to exclude beads merely adherent on the surface of the cells. Differences in the number of beads/cell between the four treatments of cells from the five subjects were tested with the Student's $t$ test for paired data.

\section{Results}

Figure 1 shows the frequency distribution of the numbers of P6-coated beads/cell in neutrophils from one subject. The distribution of beads in all treatments was not normally distributed but opsonisation of beads with $\operatorname{IgA}$ antibodies or the treatment of the cells with GM-CSF resulted in a shift in the distribution as more beads were phagocytosed by the neutrophils. The shift in distribution was particularly striking when neutrophils treated with GM-CSF were incubated with beads that had been opsonised with IgA.

The results show that a significant number of neutrophils in all treatments contained no beads, although beads were often observed to be adherent to the surface of the cells. It is possible, therefore, that these adherent beads were destined to be internalised had the period of phagocytosis been prolonged.

Figure 2 shows the average number of beads phagocytosed by neutrophils obtained from the five donor subjects. The phagocytosis of $\operatorname{IgA}$ opsonised beads by untreated neutrophils (mean (SE) $2 \cdot 1(0 \cdot 43)$ beads/cell) was significantly greater than that of non-opsonised beads (mean (SE) $1 \cdot 3(0.30)$; $p<0.01)$. Treatment of neutrophils with GM-CSF also resulted in increased phagocytosis of non-opsonised beads (mean (SE) 
$2 \cdot 1(0.39) ; \mathrm{p}<0.05)$ but opsonisation with IgA increased this further (mean (SE) $3 \cdot 4(0.53) ; \mathrm{p}<0.02)$.

\section{Discussion}

$H$ influenzae is implicated as a major pathogen in several lung diseases associated with airway infections. ${ }^{1-5}$ The bronchial secretions of patients with bronchiectasis, especially purulent sputum, contain high concentrations of total $\operatorname{IgA}^{21}$ and the serum and sputum titres of specific IgA antibodies to $H$ influenzae are also increased. ${ }^{19}$ The P6 outer membrane protein $(\mathrm{Mr} 16.6 \mathrm{kDa})$ is a major antigenic determinant of $H$ influen$z a e,{ }^{1822}$ the molecular structure being highly conserved in all strains of the bacterium. ${ }^{17}$ The P6 protein and IgA isolated from patients with $H$ influenzae infections are therefore convenient and appropriate reagents for studies of the factors affecting neutrophil recognition and phagocytosis of pathogenic organisms.

Antibodies of the IgA isotype are considered to be an important component of the host immune defence system, but their role as opsonins for neutrophil recognition of antigens has been controversial. ${ }^{8-15}$ In the present study phagocytosis of IgA opsonised beads by untreated neutrophils was significantly greater than that observed for controls where untreated neutrophils were incubated with non-opsonised P6-coated beads. These results therefore support previous reports ${ }^{12-15}$ that blood neutrophils can recognise and respond to IgA antibodies opsonising an antigen and imply an important interaction between IgA antibody production and neutrophil recruitment in response to bacterial infections. This behaviour is presumably mediated by binding to the IgA Fc receptors normally expressed on blood neutrophils. ${ }^{12} 151623$

Our results with $\mathrm{P} 6$ outer membrane protein from $H$ influenzae and P6 reactive IgA confirm those of Weisbart et $a l^{16}$ in showing that phagocytosis by neutrophils of antigen coated particles is particularly efficient if the cells are treated with GM-CSF and the antigen is opsonised with IgA antibodies. Weisbart et al also showed that the effect of GM-CSF on phagocytosis was accompanied by a change in the characteristics of surface receptors for IgA Fc from low to high affinity. Although they recorded increased phagocytosis by neutrophils in response to IgA opsonisation or treatment of the cells with colony stimulating factors, these effects were not statistically significant. They therefore suggested that the recognition by neutrophils of opsonising IgA was only significant after an increase in receptor affinity resulting from exposure of the cells to colony stimulating factors, indicating synergy. In contrast to the report of Weisbart et al, however, we observed significant increases in phagocytosis of P6-coated beads opsonised with IgA or after incubation of the cells with GM-CSF at the same concentration as that used in their study. ${ }^{16}$ Furthermore, our results suggest that the combined effects of these agents were additive and no evidence for synergy was observed.

It therefore appears that colony stimulating factors have the potential to stimulate the phagocytosis by neutrophils of both opsonised and non-opsonised bacteria. The mechanism responsible for this "upregulation" of phagocytosis of non-opsonised P6 remains unknown. Non-opsonised phagocytosis of bacteria may be mediated through the recognition by neutrophils of carbohydrate or protein components of bacteria. ${ }^{24} 25$ Since the P6 outer membrane protein is not glycosylated, peptide sequences on this protein are candidates for recognition by the neutrophils. Integrins have been identified as receptors for some bacterial ligands. The P6 sequence does not contain an Arg-Gly-Asp sequence, ${ }^{26}$ but this does not preclude recognition of this protein by receptors of the integrin family ${ }^{27}$ or other adhesion molecules on neutrophils. Neutrophil adherence is increased by GM$\mathrm{CSF}^{28}$ and the upregulation of non-opsonised phagocytosis by GM-CSF would be consistent with an increased expression or affinity of adhesion molecules which recognise the P6 protein. Further studies will be required to identify the neutrophil receptor and the target peptide on P6.

Various cells in the lung, including fibroblasts, epithelial cells, and activated macrophages and lymphocytes, have the potential to express GM-CSF. ${ }^{29-31}$ Further studies should elucidate the mechanisms which determine the production of GM-CSF by lung cells and the role of this cytokine in regulating the antimicrobial effects of IgA and neutrophils. The stimulating effects of GMCSF on phagocytosis of bacteria by neutrophils and its ability to prolong neutrophil survival $^{32}$ suggest a potential therapeutic role for this cytokine in augmenting the immune response within the lung. The effective concentrations of GM-CSF within the lung are not known at present, however, and this would need to be established before such therapy could be considered. In addition, the effects of GM-CSF on other cells will be wide ranging and some may have harmful consequences. The benefits of supplementation therapy to enhance phagocytosis would therefore need to be balanced against any potential detrimental effects in the lung.

These observations contribute to our understanding of the human immune response to non-typeable $H$ influenzae. Previous studies have shown that the sputum and serum of patients with chronic lung diseases contain IgA antibodies to $H$ influenzae, ${ }^{6} 1933$ but the functional capabilities of these antibodies have not been established. The present study has shown that IgA antibodies which recognise a specific surface antigen on $H$ influenzae are capable of stimulating opsonophagocytosis by neutrophils. The observation that these antibodies recognise the P6 outer membrane protein may be particularly relevant in view of the interest in P6 as a vaccine antigen. ${ }^{5}$ 
This work was supported by the British Lung Foundation, the Faculty of Medicine and Dentistry Research Fund (University of Birmingham), and research grant AI 19641 from the National Institutes of Health (USA).

1 Murphy TF, Apicella MA. Nontypeable Haemophilus influenzae: a review of clinical aspects, surface antigens, and the human immune response to infection. Rev Infect Dis 1987;9:1-15.

2 Pye A, Johnson MM, Burnett D, Stockley RA, Hill SL. The quantitation and source of bacteria in lung secretions from patients with bronchiectasis. Am Rev Respir Dis 1991;143(part 2):A474 (abstract).

3 Gilligan PH. Microbiology of airway disease in patients with cystic fibrosis. Clin Microbiol Rev 1991;4:830-6.

4 Musher DM, Kubitschek KR, Crennan J, Baughn RE. Pneumonia and acute febrile tracheobronchitis due to Haemophilus influenzae. Ann Intern Med 1983;99: 444-50.

5 Murphy TF, Sethi S. State of the art: bacterial infection in chronic obstructive pulmonary disease. Am Rev Respir Dis 1992;146:1067-83.

6 Groenveld K, Eijk PP, van Alphen L, Jansen HM, Zanen HC. Haemophilus influenzae infections in patients with chronic obstructive pulmonary disease despite specific antibodies in serum and sputum. Am Rev Respir Dis 1990;141:1316-21.

7 Merrill WW, Naegel GP, Olchowski JJ, Reynolds H. Immunoglobulin $\mathbf{G}$ subclass proteins in serum and lavage fluid of normal subjects. Quantitation and comparison with immunoglobulins A and E. Am Rev Respir Dis 1985;131:584-7.

8 Quite PG, Messner RP, Williams RC. Phagocytosis in subacute bacterial endocarditis. Localization of the primary opsonic site to Fc fragment. $\mathcal{f}$ Exp Med 1968;128 553-70.

9 Reed WP. Serum factors capable of opsonizing Shigella for phagocytosis by polymorphonuclear neutrophils. Immunology 1975;28:1051-9.

10 Wilson JD. Studies on the opsonic activity of human secretory IgA using an in vitro phagocytosis system. f Immunol 1972;108:726-30.

11 Zipursky A, Brown EJ, Bienenstock J. Lack of opsonization potential of $11 \mathrm{~S}$ human secretory $\gamma \mathrm{A}$. Proc Soc Exp Biol Med 1973;142:181-4.

12 Fanger MW, Goldstine SN, Shen L. Cytofluorographic analysis of receptors for IgA on human polymorphonuclear cells and monocytes and the correlation of receptor expression with phagocytosis. Mol Immunol 1983;20: 1019-27.

13 Kaplan ME, Dalmasso AP, Woodson M. Complementdependent opsonization of incompatible erythrocytes by human secretory IgA. F Immunol 1972;108:275-81.

14 Yeaman GR, Kerr MA. Opsonization of yeast by human serum IgA anti-mannan antibodies and phagocytosis by human polymorphonuclear leucocytes. Clin Exp Immunol 1987;68:200-8.

15 Albrechtsen M, Yeaman GR, Kerr MA. Characterization of the IgA receptor from human polymorphonuclear leucocytes. Immunology 1988;64:201-5.

16 Weisbart RH, Kacena A, Schuh A, Golde DW. GM-CSF induces human neutrophil IgA-mediated phagocytosis by an IgA Fc receptor activation mechanism. Nature 1988;332:647-8.

17 Nelson MB, Munson RS, Apicella MA, Sikkema DJ,
Molleston JP, Murphy TF. Molecular conservation of the P6 outer membrane protein among strains of Haemophilus influenzae: analysis of antigenic determinants, gene sequences, and restriction fragment length polymorphisms. Infect Immunol 1991;59:2658-63.

18 Murphy TF, Bartos LC, Rice PA, Nelson MB, Dudas KC, Apicella MA. Identification of a 16,600-Dalton outer membrane protein on nontypeable Haemophilus influenzae as a target for human serum bactericidal antibody. $\mathcal{F}$ Clin Invest 1986;78:1020-7.

19 Hill SL, Stockley RA, Burnett D. The specific antibody response to non-typeable Haemophilus influenzae. Am Rev Respir Dis 1989;139(part 2):abstract 37.

20 Jepsen LV, Skottun TA. A rapid one-step method for the isolation of human granulocytes from whole blood. Scand f Clin Lab Invest 1982;42:235-8.

21 Burnett D, Hill SL, Bradwell AR, Stockley RA. IgA subclasses in sputum from patients with bronchiectasis. Respir Med 1990;84:123-7.

22 Murphy TF, Campagnari AA, Nelson MB, Apicella MA. Somatic antigens of Haemophilus influenzae as vaccine components. Pediatr Infect Dis $\mathcal{F} 1989 ; 8:$ : $66-8$.

23 Fanger MW, Shen L, Pugh J, Bernier GM. Subpopulations of human peripheral granulocytes and monocytes express receptors for IgA. Proc Natl Acad Sci USA 1980;77:3640-4

24 Ofek I, Sharon N. Lectinophagocytosis: a molecula mechanism of recognition between cell surface sugars and lectins in the phagocytosis of bacteria. Infect Immunol 1988;56:539-47.

25 Naids FL, Belisle B, Lee N, Rest RF. Interactions of Neisseria gonorrhoeae with human neutrophils: studies with purified PII (Opa) outer membrane proteins and synthetic Opa peptides. Infect Immunol 1991;59. 4628-35.

26 Nelson MB, Apicella MA, Murphy TF, Vankeulen $H$ Spotila LD, Rekosh D. Cloning and sequencing of Haemophilus influenzae outer membrane protein P6. Infect Immunol 1988;56:128-34.

27 Hogg N. The leukocyte integrins. Immunol Today 1989, 10:111-4.

28 Chamba A, Afford SC, Stockley RA, Burnett D Extracellular proteolysis of fibronectin by neutrophils: characterization and the effects of recombinan cytokines. Am f Respir Cell Mol Biol 1991;4:330-7.

29 Itoh A, Yamaguchi E, Kazumaki N, Okazaki N, Furuya $\mathrm{K}$, Shosaku A, et al. Expression of granulocytemacrophage colony-stimulating factor mRNA in inflam-
matory cells in the sarcoid lung. Am $\mathcal{F}$ Respir Cell Mol matory cells in the

30 Smith SM, Lee DKP, Coleman DL. Rat tracheal epithelial cells produce granulocyte/macrophage colony-stimulating factor. Am $\mathcal{F}$ Respir Cell Mol Biol 1990;2:59-68.

31 Vancheri C, Gauldie J, Bienenstock J, Cox G, Scicchitano $R$, Stanisz A, et al. Human lung fibroblast-derived granulocyte-macrophage colony-stimulating factor (GM CSF) mediates eosinophil survival in vitro. Am $\mathcal{F}$ Respir Cell Mol Biol 1989;1:289-95.

32 Brach MA, de Vos S, Gruss H-J, Hermann F Prolongation of survival of human polymorphonuclear neutrophils by granulocyte-macrophage colony-stimulating factor is caused by inhibition of programmed cell lating factor is caused by inhibit

33 Musher DM, Goree A, Baughn RE, Birdsall HH Immunoglobulin A from bronchopulmonary secretion blocks bactericidal and opsonizing effects of antibody to nontypeable Haemophilus influenzae. Infect Immunol 1984;40:36-40. 